\title{
Upstream stacking of thickened tailings at Neves Corvo
}

\author{
R Lopes Golder Associates Ltd., Canada \\ R Bahia Golder Associates Portugal Unipessoal Lda, Portugal \\ M Jefferies Golder Associates (UK) Ltd, UK \\ M Oliveira Somincor, Portugal
}

\begin{abstract}
Neves Corvo is a world-class underground copper-zinc mine located in the south of Portugal. The mine has been operating since 1988 by Somincor (Sociedade Mineira de Neves-Corvo SA), a wholly-owned subsidiary of Lundin Mining Corporation from Canada.

The pyritic tailings produced has a very high acid generation potential and until 2010 had been placed subaqueously in the Barragem Cerro do Lobo (BCL), a large tailings pond (190 ha) created by a rockfill dam, $42 \mathrm{~m}$ high, across a natural water course. In late 2010 Somincor switched to using subaerial paste/thickened tailings deposition over the existing subaqueous slurry deposit. This approach accommodates the required 17.4 Mt storage capacity from 1 January 2010, as per Somincor's 2005 life-of-mine (LOM) plan, and allows maintaining the existing perimeter embankment at its current elevation and facilitates site closure (Lopes et al. 2013).
\end{abstract}

The results of the first two years of operation of the paste production plant and depositional performance of the first 2 to $4 \mathrm{~m}$ of paste/thickened tailings over the very loose subaqueous deposit, were presented at Paste 2013 in Brazil (Lopes et al. 2013).

Somincor's 2014 LOM studies have established additional reserves and related demand for additional tailings and mine waste rock storage at the Neves Corvo tailings storage facility (TSF) beyond the 2005 deposition design. Specifically an increase of up to $27 \mathrm{Mt}$ of tailings and as much as $10 \mathrm{Mt}$ of mine waste rock need to be accommodated into an expanded Neves Corvo TSF, relative to the 2005 design.

Following an evaluation of alternatives for expansion of the TSF, upstream stacking of thickened tailings at an overall slope of 4 to $6 \%$ is the selected solution. The upstream stacking solution decouples the desired stacking slope from the beach slope variability inherent to the operation at this site (Lopes et al. 2013).

A critical aspect of this design approach is that the rate of rise of the stack cannot exceed the rate of strength gain of the thickened tailings and underlying subaqueous tailings. This is assured by continuous monitoring of tailings pore pressure at piezometer installations and by periodic CPTU testing of the deposit. In addition, laboratory testing of settling, drying and consolidation behaviour of the thickened tailings was performed to assist in the interpretation of the observed field data and to forecast stability of the proposed final landform.

Some operational changes have been made to the previous deposition into cells from a single point of discharge. An array of perimeter spigots is now used to assure a wider spreading of the tailings over the operating area and promote faster drying and strength gain. In addition the frequent cycling of discharge spigot locations and the final cover design will assure a high level of saturation of the raised landform, in order to control acid generation and metal mobilisation. 


\section{Introduction}

Neves Corvo is the largest mine in Portugal, located near Castro Verde, some $220 \mathrm{~km}$ south of Lisbon (Figure 1), on the western edge of the Iberian Pyritic Belt. The local climate is semi-arid, with average annual precipitation of $484 \mathrm{~mm}$, mostly occurring between October and April, and evaporation of about $1,313 \mathrm{~mm}$ per year.

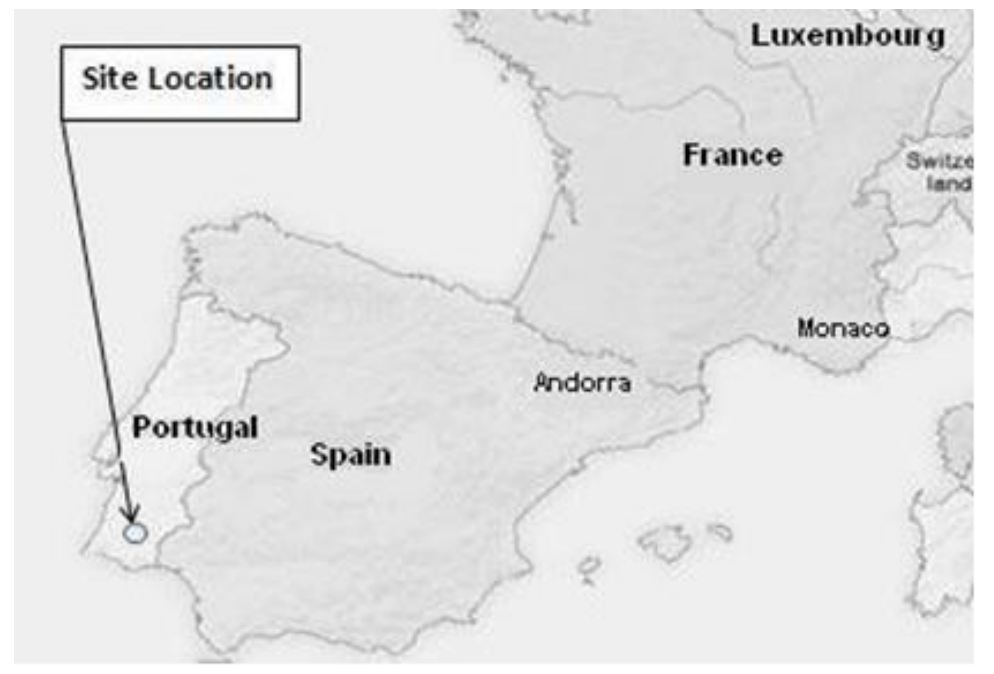

\section{Figure 1 Site location}

The underground mine has been operating since 1988 by Somincor (Sociedade Mineira de Neves-Corvo SA), a wholly-owned subsidiary of Lundin Mining Corporation from Canada.

The tailings produced in the copper and zinc plants are sulphide-rich, comprising 40 to $50 \%$ pyrite $\left(\mathrm{FeS}_{2}\right)$ by mass. They have very high net acid generating potential, with the acid potential (AP) between approximately 700 and $800 \mathrm{~kg} \mathrm{CaCO}_{3} / \mathrm{t}$ and the neutralising potential (NP) averaging $30 \mathrm{~kg} \mathrm{CaCO} / \mathrm{t}$.

Tailings have been disposed since the start of the mine operations in the Instalação de Resíduos de Cerro do Lobo (IRCL) tailings storage facility (TSF) using subaqueous deposition methods to control oxidation of the sulphides.

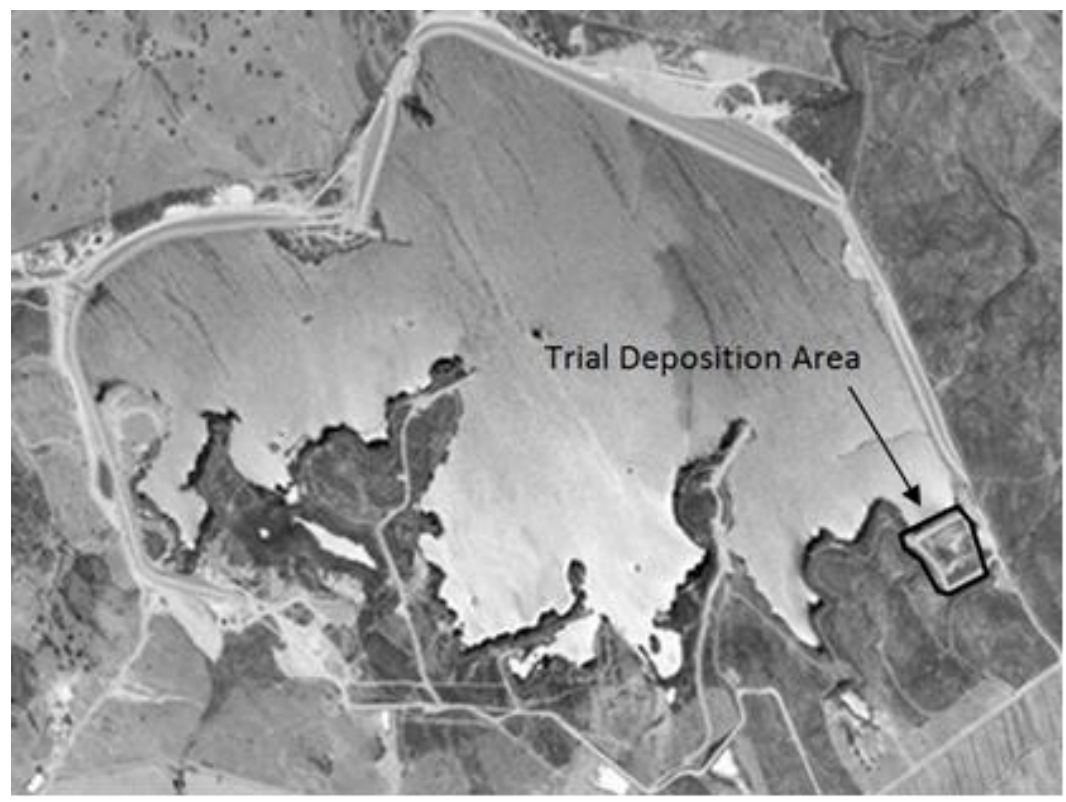

Figure 2 Neves Corvo TMF - year 2006 
Somincor's 2005 LOM plan envisaged ore production rates of 1.5-2.5 Mt per annum and at these production rates the subaqueous deposition capacity of the IRCL would be exhausted by 2011 . Therefore in 2005 Somincor commissioned a feasibility study focused on providing the required 2005 LOM Plan capacity through use of thickened/paste tailings technology.

The feasibility study included the installation in 2005 of a $20 \mathrm{~m}^{3} / \mathrm{h}$ paste pilot plant and one hectare trial deposition area at the location shown on Figure 2. The trial deposition was completed between April and November 2005. Results of the trial deposition were published most recently at the 2009 ICARD conference in Sweden (Verburg et al. 2009).

The main elements of the 2005 LOM expansion design were as follows (Oliveira et al. 2011):

- Deposition of thickened tailings/paste sequentially into 15 cells, each with approximately six months to one year capacity and maximum tailings elevation of 260 mASL ( 5 m above perimeter dam crest).

- The cells are separated by mine waste rock dykes, which include a co-deposition element in the expansion design. Alternating deposition between cells and limiting lift thicknesses promotes drying and densification of the deposited tailings.

- The sequential cell filling and placement of final cover allows for progressive site restoration and better control of acid generation and runoff during the operating years.

- Modelling of post-closure drawdown of the water table in the deposit, and predictions of long term environmental performance indicate that the use of a common soil cover (similar to regional surface soils) would be best in order to promote a high degree of saturation and low oxidation rates in the deposit (Junqueira et al. 2009).

A plan view and cross section of the proposed completed facility, as per the 2005 LOM Plan, are given in Figure 3. 


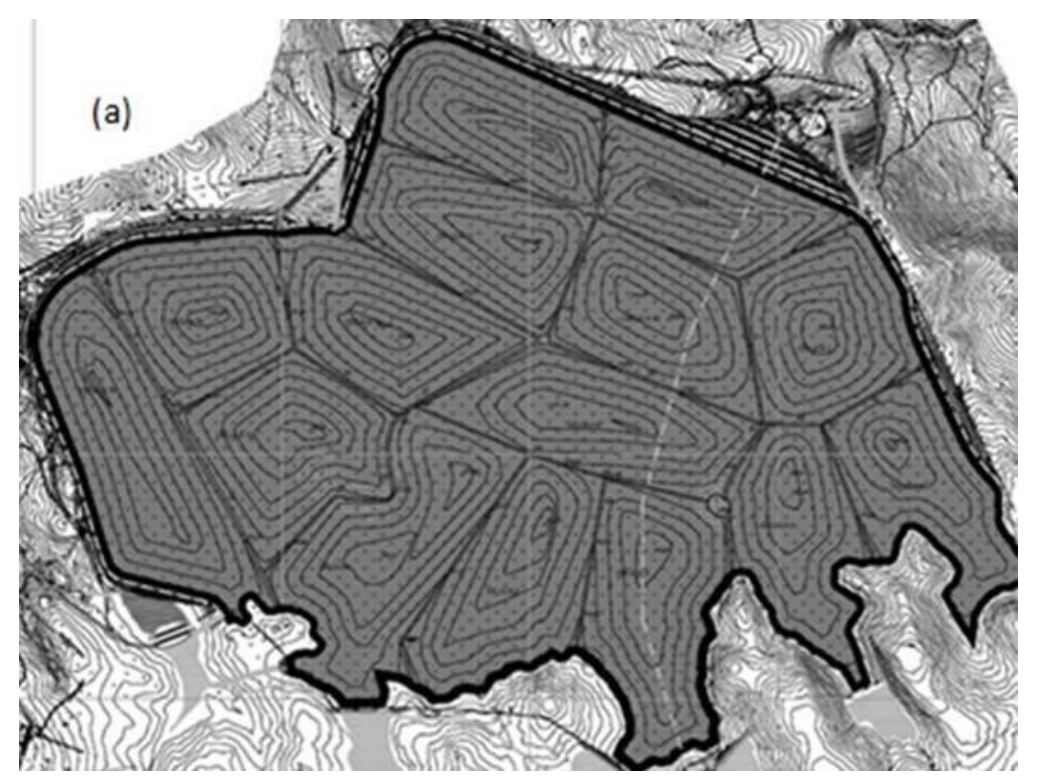

(a)

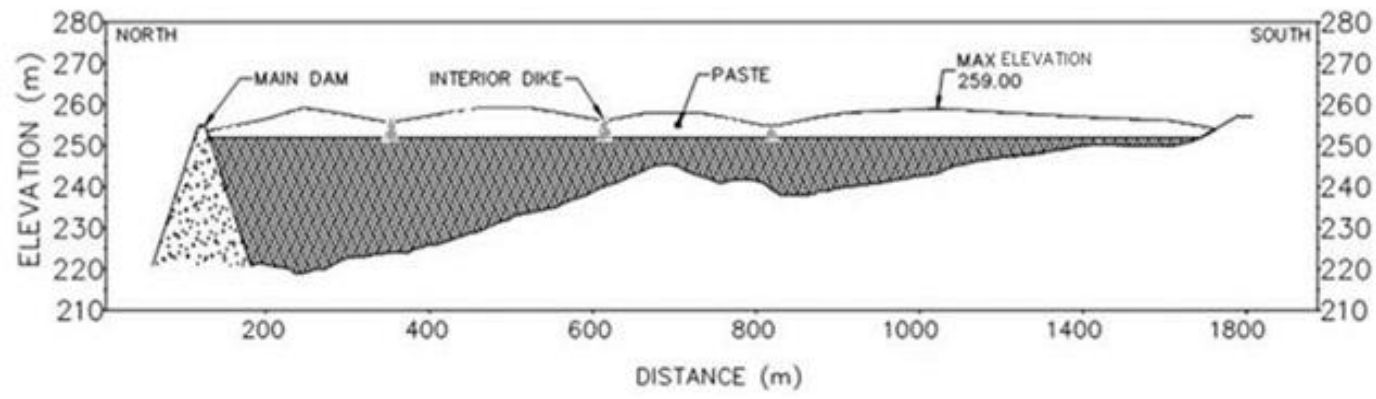

(b)

Figure 32005 LOM paste deposit design; (a) plan view; and (b) cross section

The 2005 LOM plan envisaged a maximum tailings elevation of $260 \mathrm{mASL}$, or a maximum of $5 \mathrm{~m}$ above perimeter dam crest. An aerial photograph of the progress of paste deposition at July 2013 is shown in Figure 4. 


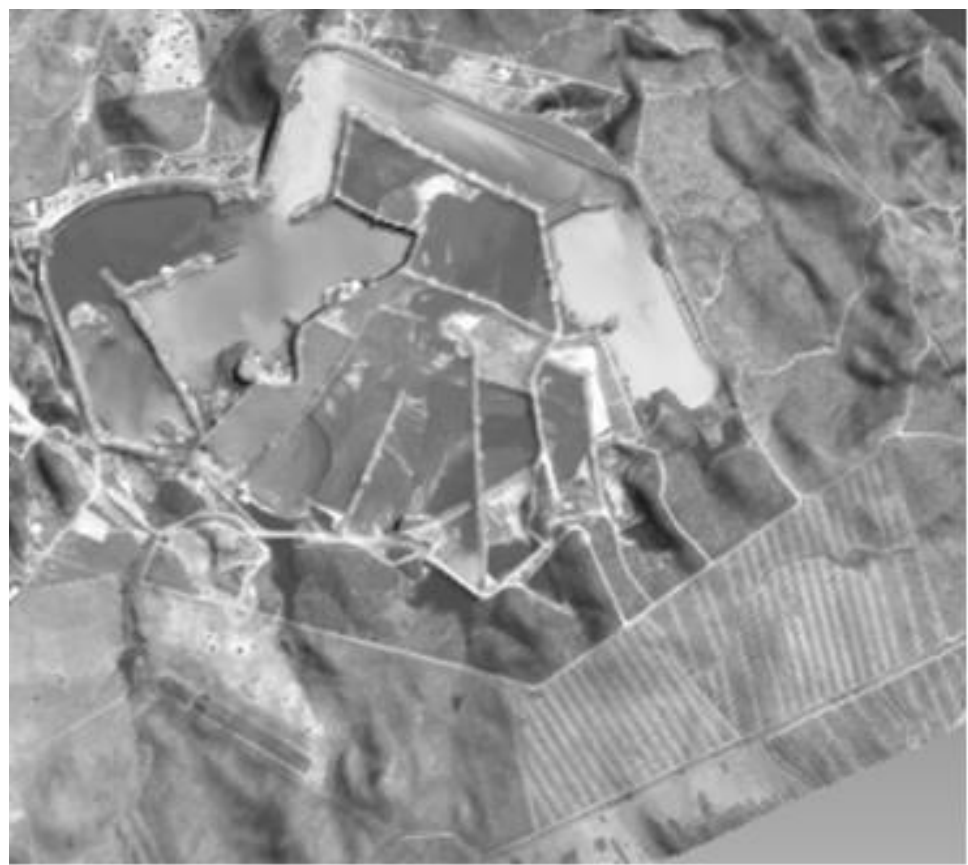

\section{Figure 4 Aerial view of deposition progress at July 2013}

A description and discussion of the challenges encountered during the first two years of operation of the paste deposition project (November 2010 to November 2012) was given at Paste 2013 (Lopes et al. 2013).

In 2014 Somincor undertook LOM studies which require the expansion of the Neves Corvo TSF for addition of up to $27 \mathrm{Mt}$ of tailings and $10 \mathrm{Mt}$ of mine waste rock, in relation to the $2005 \mathrm{LOM}$ design. The following section of this paper describes the alternative design concepts analysed for that significant expansion.

\section{TSF capacity expansion alternatives}

The 2014 LOM studies included the evaluation of two tailings and mine waste rock disposal scenarios:

1. A Base Case Scenario requiring storage for $30 \mathrm{Mt}$ of mine waste (21 Mt of tailings plus $8.8 \mathrm{Mt}$ of mine waste rock) within the existing IRCL footprint, from January 2014 until 2024.

2. An Expansion Scenario requiring storage for $50 \mathrm{Mt}$ of mine waste ( $36.2 \mathrm{Mt}$ of tailings and $13.6 \mathrm{Mt}$ of mine waste rock) from January 2014 until 2034, by raising the IRCL dam walls and/or expanding the TSF footprint to new areas, including out of the present Somincor property limits.

The above numbers include an estimated 4.7 Mt of mine waste rock present in the waste dump at 1 January 2014. Considering the expected evolution of tailings grain size and specific gravity and corresponding in situ densities, these two scenarios will imply 16.3 and $25.5 \mathrm{Mm}^{3}$ deposition capacities, respectively.

Somincor commissioned Golder to prepare a conceptual design of expansion of the existing (1 January 2014) Neves Corvo tailings facility (IRCL) in accordance with each of the two above scenarios. The findings and recommendations of that conceptual design study are summarised in the following sections.

\subsection{Base case scenario - alternatives evaluated}

For base case LOM scenario, the presently outlined deposition strategy limits the deposit footprint to the existing IRCL boundary and the required deposition volume capacity can be achieved by the raising of a stack at $4 \%$ overall slope generated by ten tiers of upstream discharge of thickened tailings deposition from perimeter containment berms. The maximum tailings elevation in this concept would be $277.5 \mathrm{mASL}$ or some $22.5 \mathrm{~m}$ above the existing perimeter dams. 
For comparison purposes a design concept comprising raising of the perimeter dam walls (as opposed to stacking tailings above the perimeter dams) to achieve the required capacity, was also analysed. This required raising the perimeter dams by $10 \mathrm{~m}$. An illustration of the two alternative design concepts is given in Figure 5.

\section{Base Case Stacking Strategy Alternative - Long Section Profile}

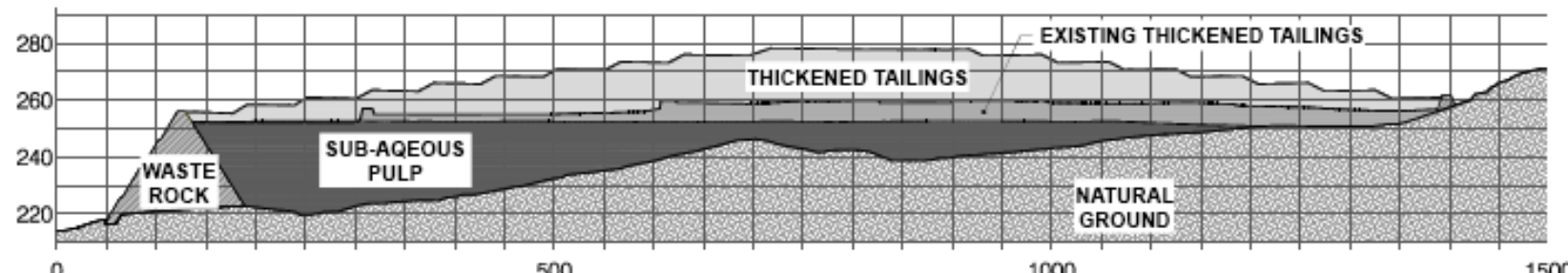

Base Case Full Containment Strategy Alternative - Long Section Profile

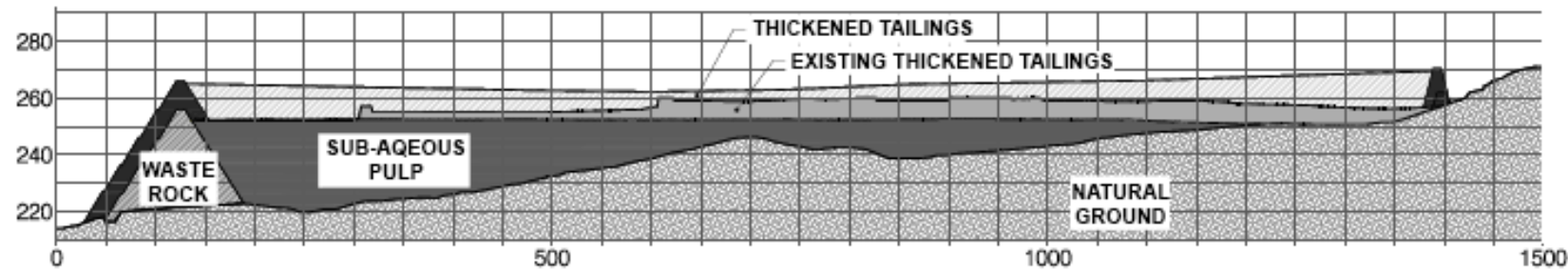

Base Case Strategies Comparison - Long Section Profile

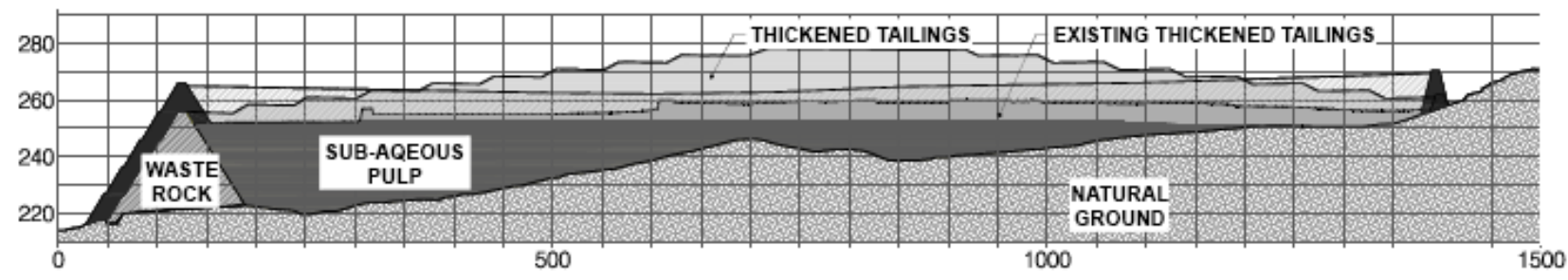

Figure 5 Illustration of expansion options maintaining existing footprint (base case)

A multi-parameter (cost, schedule and environmental risk) comparative evaluation of these alternatives favoured the upstream stacking concept.

\subsection{Expansion scenario - alternatives evaluated}

Several lateral and upstream footprint expansion alternatives to meet the required capacity for $36.2 \mathrm{Mt}$ of tailings and 13.6 Mt of mine waste rock from January 2014 were evaluated, as illustrated in Figure 6.

Illustrative profiles of the footprint expansion options for the larger capacity expansion case, are given in Figure 7 below the plan view. 


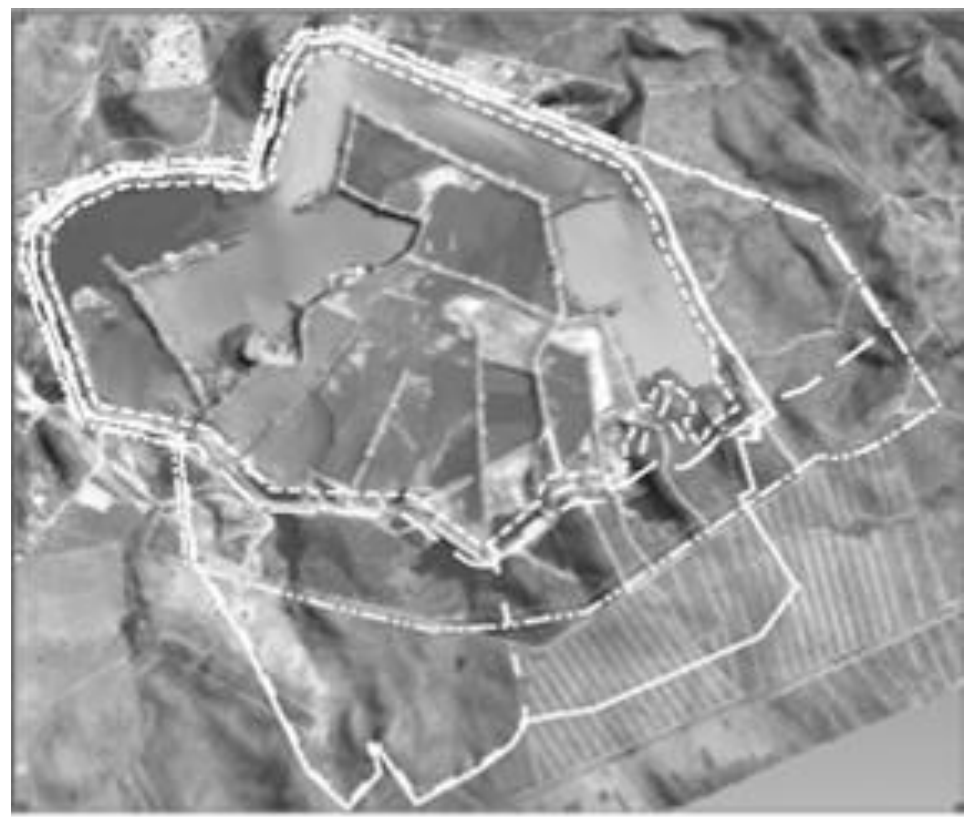

Figure 6 Neves Corvo TSF footprint expansion alternatives studied

LoM Expansion Case - Stacking Plus Footprint Expansion Strategy - Long Section Profile

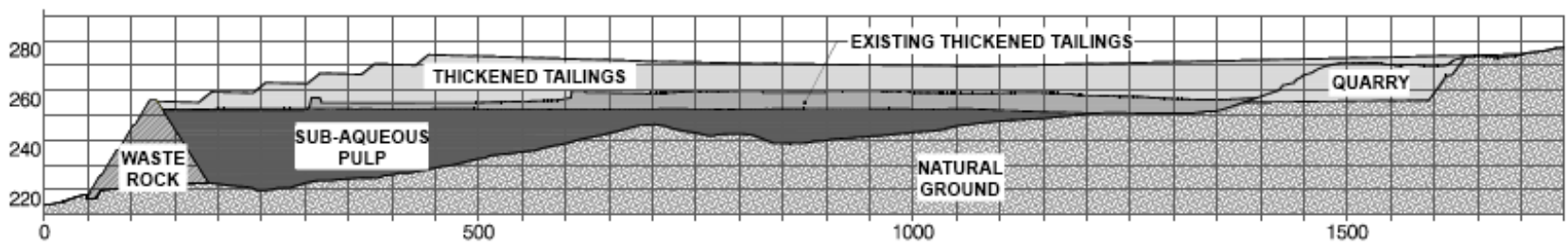

LoM Expansion Case - Full Containment Plus Footprint Expansion Strategy - Long Section Profile

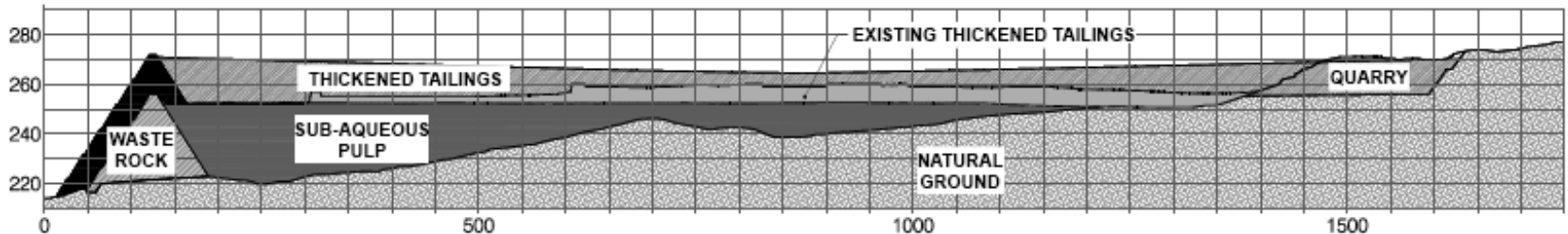

LoM Expansion Case - Strategies Comparison - Long Section Profile

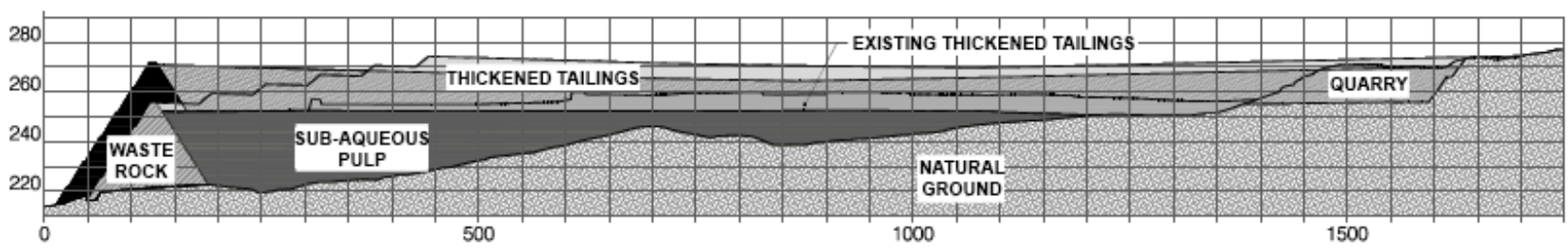

Figure 7 Illustration of footprint expansion options studied (expansion case)

As in the base case, a multi parameter evaluation of these alternatives favoured the upstream stacking alternative. 


\section{$3 \quad$ Upstream stacking design considerations}

\subsection{Cell deposition experience}

As referred to in Section 1 and illustrated in Figure 3, the 2005 deposition scheme envisaged placing of thickened/paste tailings in 15 cells, to a maximum of $5 \mathrm{~m}$ above the perimeter dams. The cells were created by construction of mine waste rock dykes over the existing very loose subaqueous tailings deposit. Typical water depth above the subaqueous tailings was in the range of 0.5 to $1 \mathrm{~m}$.

The dykes were built by advancing a narrow front of mine waste rock at about 5 to $6 \mathrm{~m}$ above the supernatant pond level, which displaced the upper 2 to $4 \mathrm{~m}$ of upper subaqueous tailings and created 'mud waves' on either side of the dykes. The dykes were then widened to a minimum crest width of $6 \mathrm{~m}$ and lowered to a typical height of $4 \mathrm{~m}$ above pond level.

The cells were to be filled and covered sequentially to minimise exposure and desaturation of the paste tailings. However, due to unanticipated delays in the construction of a new tailings effluent reservoir to the southwest of the TSF it became necessary to keep a perimeter area of pond within the TSF and raise the tailings deposition in the south and central area of the TSF by an additional 3 to $6.5 \mathrm{~m}$. This vertical expansion with a setback of over $200 \mathrm{~m}$ from the perimeter dams was found to be stable.

This resulted in stacking of tailings to as much as $10 \mathrm{~m}$ above perimeter dams at the upstream and central area of the TSF since 2012 and delayed the application of clean final cover to minimise runoff from exposed desaturated tailings surfaces. Nevertheless, as shown by $\mathrm{pH}$ control of the exposed tailings, oxidation of exposed tailings surfaces has been limited to the surficial 1 to $3 \mathrm{~cm}$, under prevailing climatic and operational conditions (Lopes et al. 2013).

Although it should be possible to achieve the 4 to $6 \%$ overall mound geometry using sequential stacking within cells, as practised for the shallow deposit envisaged in the 2005 LOM plan, this would increase the potential for post closure drawdown and increased desaturation levels of the deposit, due to the extensive network of permeable mine waste rock pathways created by the dikes of the initial cell deposition methodology. In addition, performance monitoring of the thickened tailings to date indicate that deposition over larger areas and from an array of spigots should result in lower void ratios and faster strength gain in newly deposited tailings. These considerations led to the decision to change the deposition strategy for the capacity expansion to eliminating the cell dykes and building small ( $2.5 \mathrm{~m}$ height) perimeter berms of mine waste rock from which to spigot thickened tailings. Repeating this at appropriate intervals towards the centre of the desired stack will create a continuous deposit of low permeability paste at the desired overall slope, which will encapsulate the previous cell dykes and enhance the post closure saturation levels in the higher stack. In addition the final cover over the deposit has also been designed to enhance infiltration and saturation of the tailings.

The external effluent pond's recirculation water system is anticipated (at time of this writing) to be commissioned in March of 2015, at which time the existing perimeter pond area will become available for tailings deposition. In the interim, significant experience has been gained with the drying and consolidation behaviour of the deposited thickened tailings, as well as with the consolidation and pore pressure response of the underlying subaqueous deposit, for a range of deposition rates in the various active cells. This has included parallel laboratory and field geotechnical investigation and monitoring programs including:

- Laboratory column tests to investigate the settling, drying and self-weight consolidation of the thickened tailings.

- Geotechnical laboratory tests on Mostap samples of thickened tailings and slurry tailings obtained in 2012 investigations, including classification, triaxial, and consolidation tests.

- Collection of undisturbed samples of the upper $0.5 \mathrm{~m}$ of deposited thickened tailings to determine void ratio and degree of saturation after various periods of inactive deposition. 
- Fourteen vibrating wire (vw) piezometers installed in tailings below and around selected cell dykes and one in a central location within a cell.

- Cone penetration testing with piezometric measurements (CPTu) every two years to confirm strength gain of the tailings (the second bi-annual campaign was started in late 2014).

The laboratory testing and in particular the monitoring of piezometric levels in the tailings has shown that raising the tailings deposit at rates averaging 1.5 to $4 \mathrm{~m} / \mathrm{y}$ (maximum of $2 \mathrm{~m} / \mathrm{month}$ in one interior cell) and limiting internal containment dyke heights to $7 \mathrm{~m}$ has provided sufficient time for consolidation and pore pressure dissipation to maintain stability of the deposit to date. In addition, analyses assuming the expected post-liquefaction resistance of the tailings show that a stack with an overall benched slope of 4 to $6 \%$ will be seismically stable.

The results of classification testing and 2012 CPTu tests were reported in Lopes et al. (2013); the results of the subsequent studies will be reported in greater detail elsewhere. The following sections of this paper summarise some of the main findings of the overall program.

\subsection{Void ratio, consolidation and strength of paste tailings deposit}

Void ratio is the critical geotechnical parameter regarding stability of saturated tailings under rapid loading (ie. cyclic/seismic or monotonic). Therefore CPTu testing and laboratory 'critical state line' (CSL) triaxial testing (Been \& Jefferies 1985) are key steps in the evaluation of the in situ void ratio and dynamic stability of the Neves Corvo thickened tailings deposit.

Since CPTu testing provides only an indirect 'snapshot' of the void ratio condition of the tailings, it was also necessary to simulate in the laboratory the evolution of the tailings with time from discharge through the settling, drying and consolidation processes which determine its in situ void ratio and related strength behaviour. A column testing program was conducted for this purpose, as summarised below.

\subsubsection{Column test results}

Previous research (Salfate 2011) has shown that the in-situ void ratio in a thickened tailings deposit is significantly influenced by the initial or formation void ratio of the tailings. For purposes of our laboratory column testing program, the formation void ratio is the resulting void ratio from settling and self-weight consolidation of a layer of tailings.

The column testing program evaluated the influence of evaporative drying and a number of other parameters on the void ratio of the thickened tailings, including:

- Tailings particle size distribution (PSD) as characterised by $D_{50}$ size $(5,10,20$ micron).

- Layer thickness $(10,20,30 \mathrm{~cm})$.

- Range of accretion rates and duration of drying intervals (3.47 and $10.43 \mathrm{~m} / \mathrm{y}$ ).

- Range of $\%$ solid particles by mass (\%SP) in discharged tailings (60, 65, 70\%).

- Range of local evaporation rates $(4,8,12 \mathrm{~mm} / \mathrm{d})$.

The range of void ratios obtained in 24 column tests, for the above range and combination of conditions was 0.75 to 1.1. The primary conclusion of a parametric analysis is that evaporation rates and percentage solid particles by mass (\%SP) in discharge have the most significant influence on the resulting void ratios. Details of the testing procedures and more detailed analyses of the column results will be given in a separate publication at a later date.

The above range of column test results compares well with results obtained on 45 undisturbed samples collected from surface layers of deposited thickened tailings in various locations, with known variable duration of drying, which were in the range of 0.85 to 1.1 . 


\subsubsection{Odometer consolidation test results}

As part of assessing the evolution of the void ratio of the thickened tailings under load from successive layers of tailings, samples were prepared by settling and self-weight consolidation in columns of $100 \mathrm{~cm}$ height. These columns were sealed at the top so samples were not allowed to lose water through evaporation.

Four samples were prepared, each with a different \%SP (30, 50, 60 and 70\%SP). Undisturbed test specimens from the base of each column were then subjected to successive stages of increasing load, up to the equivalent of $40 \mathrm{~m}$ of submerged tailings. The resulting consolidation curves are shown in Figure 8 .

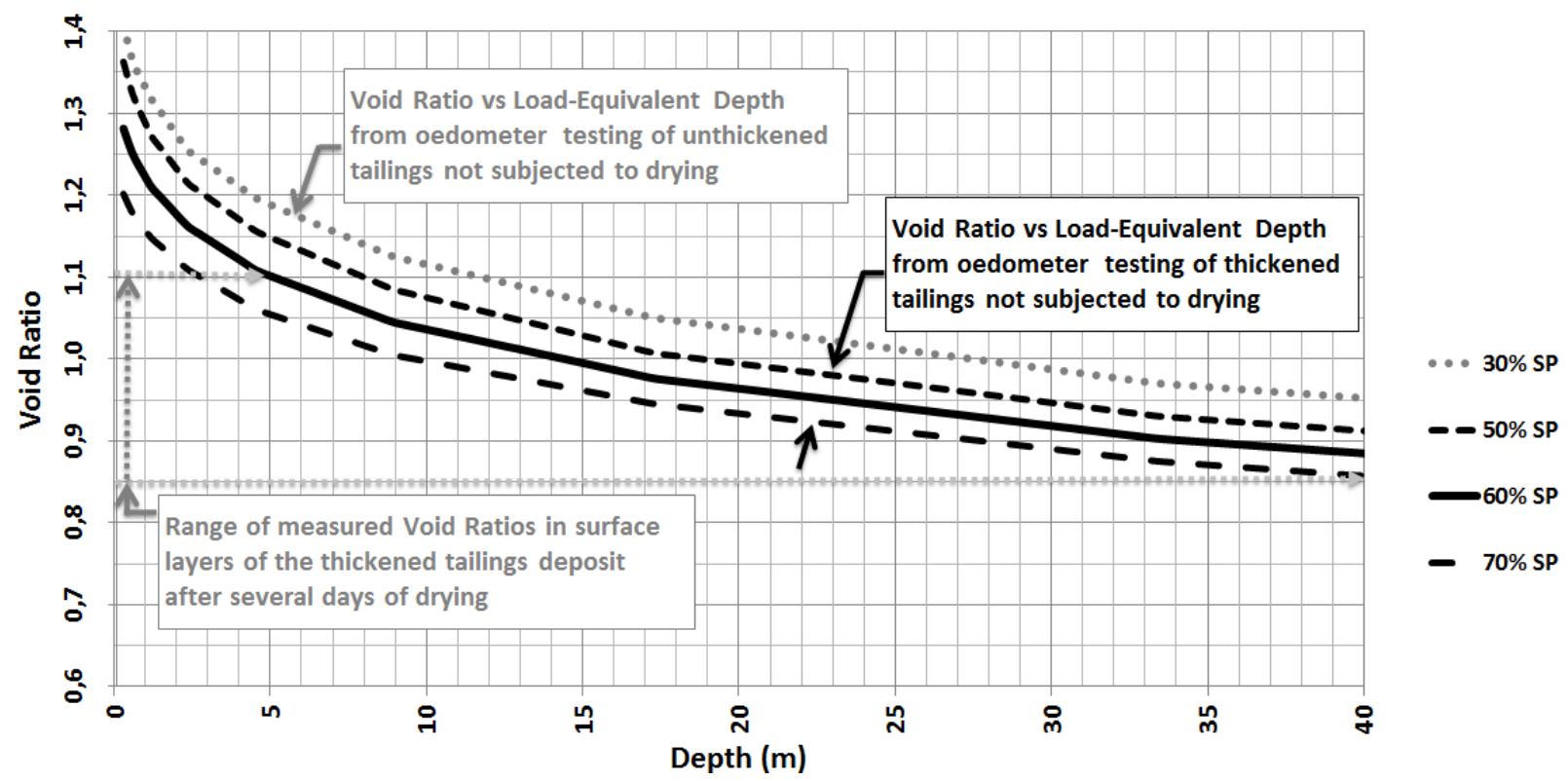

\section{Figure 8 Formation void ratio and void ratio versus depth for normal consolidation (no drying)}

Figure 8 shows that the formation void ratios for tailings not subject to drying are significantly higher than the void ratios obtained in the column studies which included all the significant variables of the Neves Corvo operation, including the local evaporation rates. Also shown on the graph is the range of void ratios measured in samples taken for the top $10 \mathrm{~cm}$ of surface layers of thickened tailings in various cells.

The above graph also suggests that drying imparts a 'pre-consolidation' effect on the thickened tailings which is equivalent to a load of 5 to $40 \mathrm{~m}$ of tailings, for the typical 60 to $70 \% \mathrm{SP}$ degree of thickening achieved by the Neves Corvo plant.

Consolidation testing of samples prepared to the range of void ratios observed in the field and in the comprehensive column studies is underway and will be reported separately at a later date.

\subsection{Observed pore pressure response of the paste and existing subaqueous deposit}

A critical aspect of the upstream stacking approach is that the rate of rise of the stack cannot exceed the rate of tailings pore pressure dissipation resulting from the tailings consolidation process. Therefore pore pressure conditions in the tailings have been monitored via three sets of piezometric investigation techniques, namely:

1. vw piezometers installed at fixed locations below and around cell containment dykes and within one cell, which allow tracking pore pressure behaviour at the given location/elevation as a function of time and loading events in its vicinity (berm/dyke construction or tailings deposition). 
2. Push-in type of vw piezometers quickly/temporarily installed in areas of interest; mainly around advancing berms built on deposited paste or in areas showing some distress or unanticipated settlement.

3. CPTu testing performed at selected locations in 2012 and in 2014 (ongoing) which provide piezometric profiles at regular vertical intervals for the date of the CPTu test.

A summary of findings of each of these types of monitoring/ investigations is given in the following subsections.

\subsubsection{CPTu results}

The 2012 CPTu dissipation tests were used to observe the progress of consolidation within the tailings, as the end-of-dissipation pressures measure the in situ pore pressure at the time of the test. The data is shown in Figure 9.
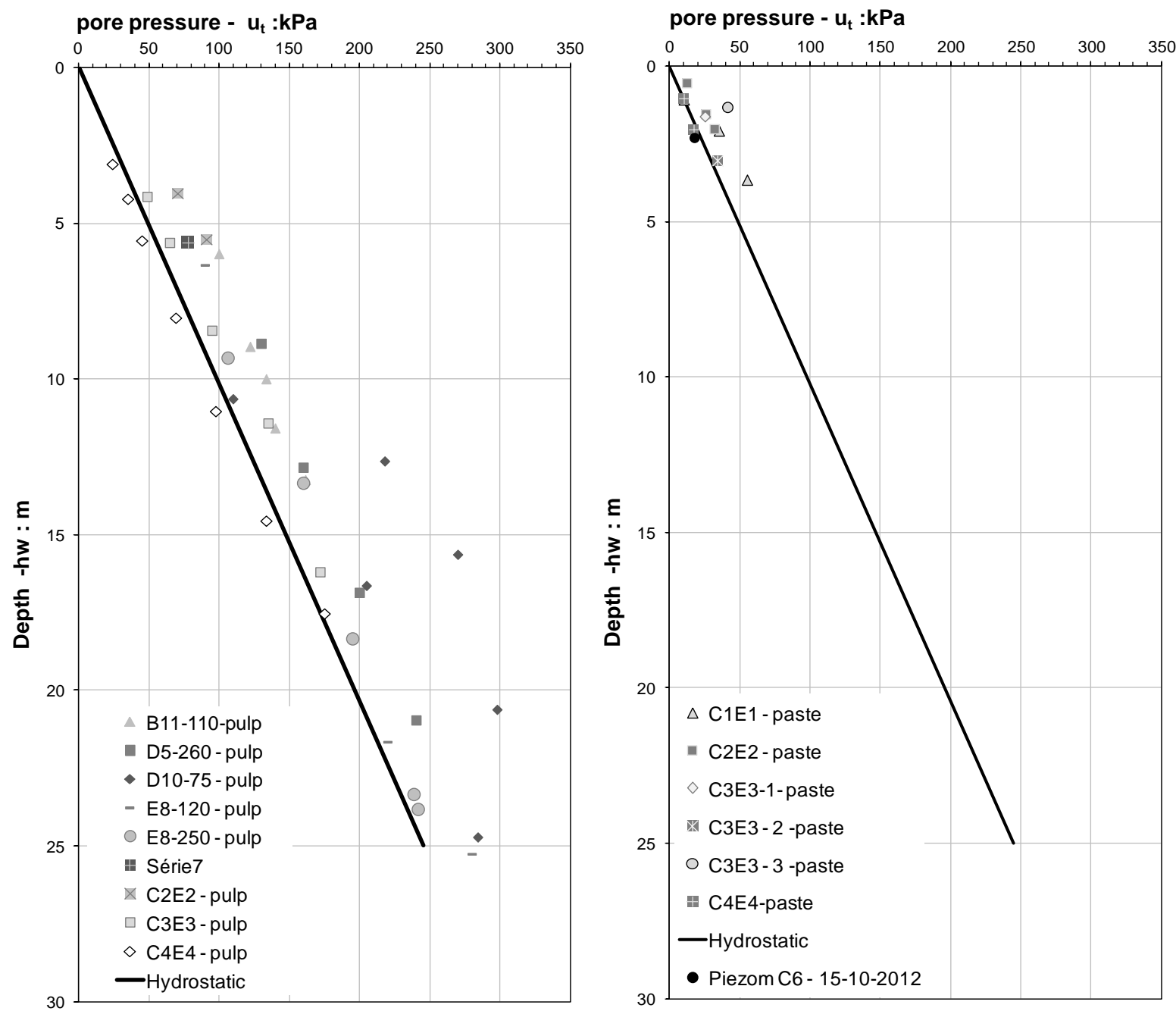

Figure 9 Measured pore pressures versus depth

In the case of subaqueous tailings, excess pore pressures range from zero (a hydrostatic condition) in cell locations where filling was stopped for over a period of three to eight months prior to the CPTu, to values as high as $100 \mathrm{kPa}$ in the tailings below a recently constructed dyke. In the case of the paste, excess pressures exist in areas of recent deposition but are only about 10-20 kPa. The calculated coefficient of consolidation $\left(C_{h}\right)$ from this data suggests that consolidation times for typical tailings thickness of 15 to $25 \mathrm{~m}$ should be about six months to perhaps a year; this affects the paste as the paste loads the underlying 
slurry tailings and the upward migration of pore water retards the consolidation of the paste (Lopes et al. 2013).

\subsubsection{Monitoring of fixed vw piezometers}

As of November 2014, some 14 vw piezometers were installed in tailings deposition and internal dyke areas and actively monitored for almost three years. Figure 10 features a location plan of these installations.

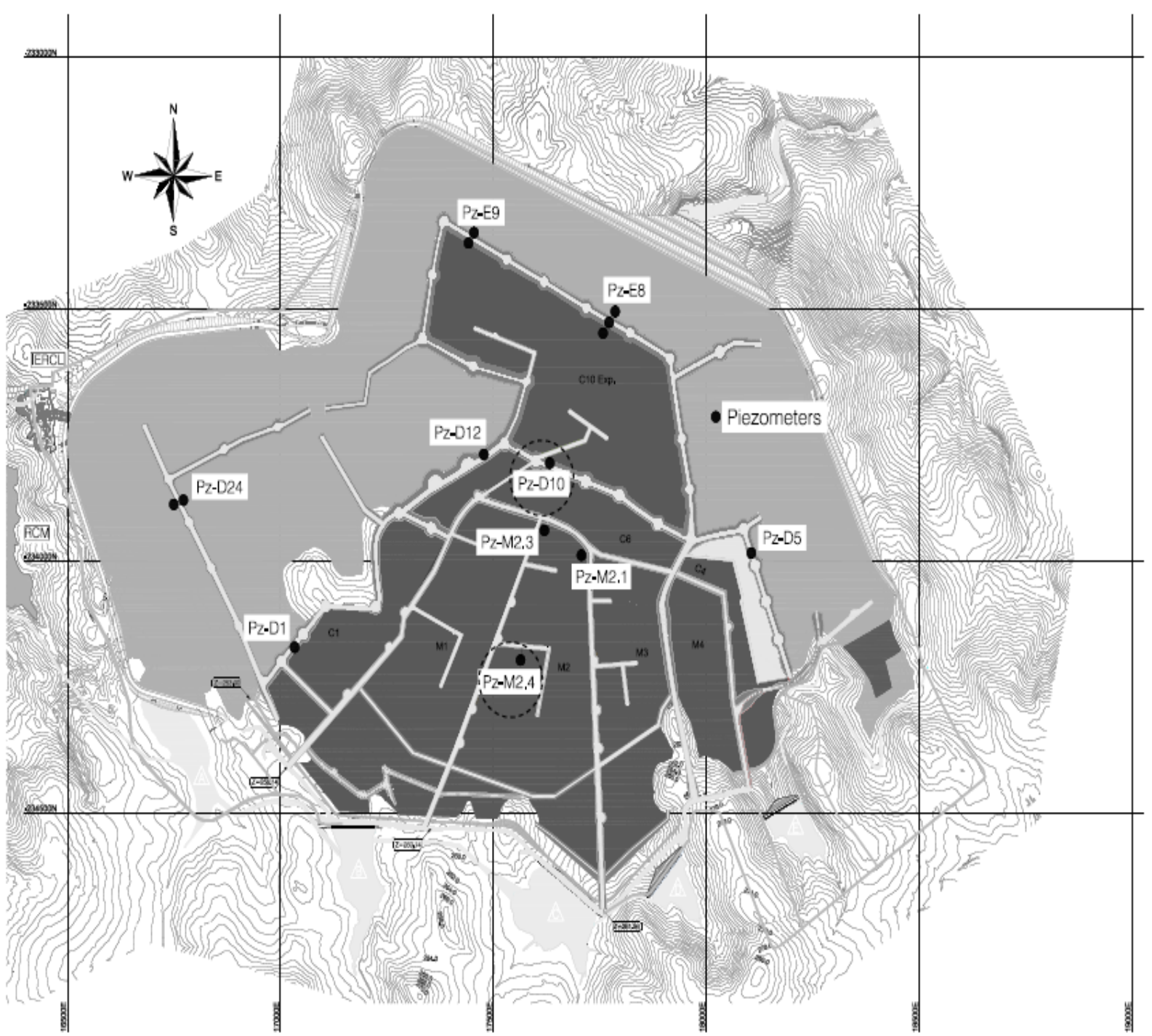

\section{Figure 10 Location plan for fixed vw piezometers}

Two piezometer installations (Pz-D10 and Pz-M2.4) have been selected to illustrate the pore pressure response of the tailings deposit under load from dyke raising and from rising deposition. Figure 11 shows the vertical location of each of the two piezometers in relation to existing tailings and mine waste berms/dykes at November 2014 and shows the approximate proposed final tailings profile at these locations, for the lower capacity expansion (base case). 

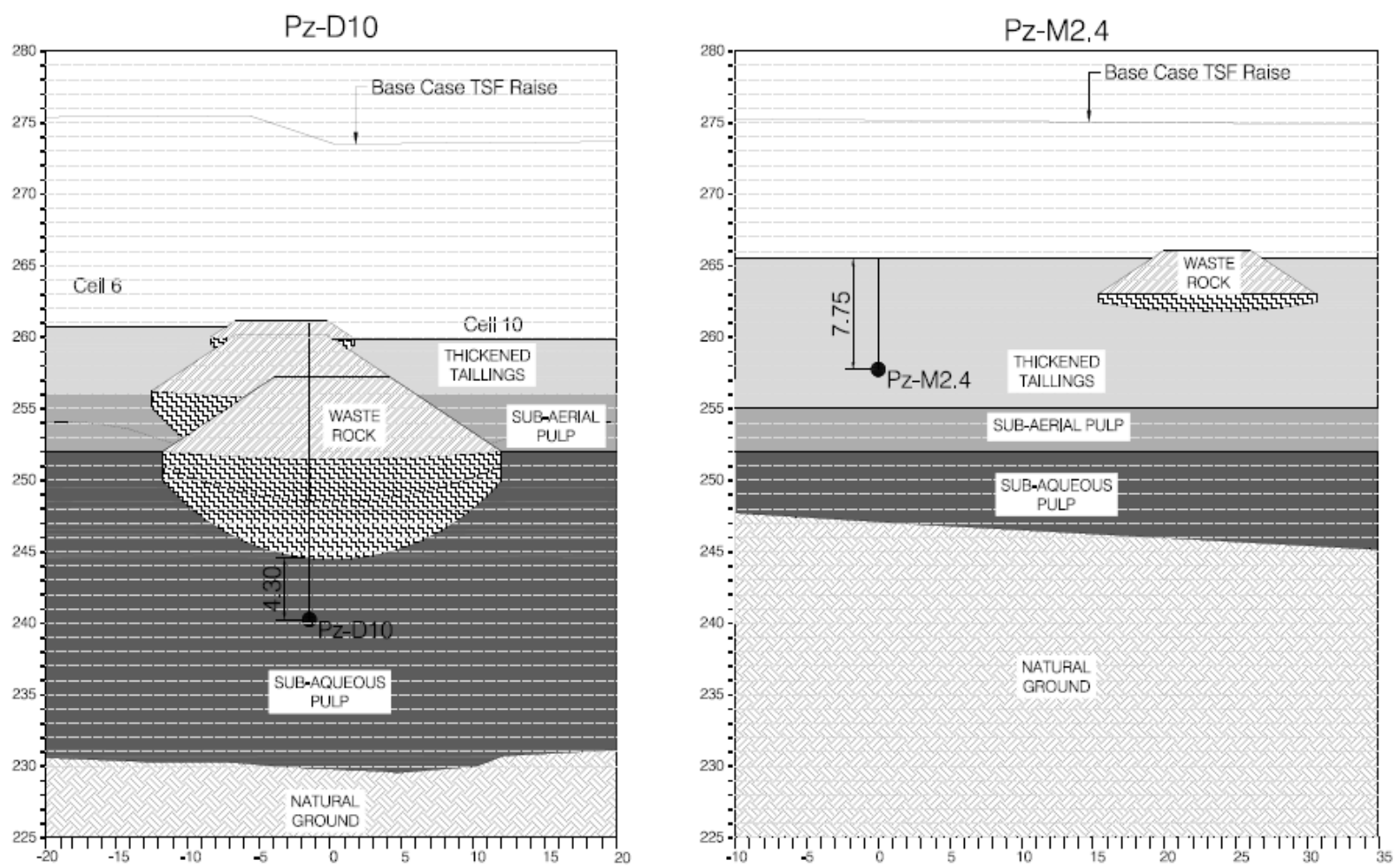

\section{Figure 11 Schematic illustration of subsurface conditions around piezometers Pz- D10 and Pz-M2.4}

Piezometer D10 is located directly in subaqueous slurry under one of the containment dykes built by displacement over the subaqueous slurry (pulp) deposit. Piezometer M2.4 is located within the paste in the interior of one of the first four cells; a spigotting berm was built recently in the proximity of this piezometer, as illustrated in Figure 11.

The time evolution of the tailings surface and pore pressure at each of these two piezometers is shown in Figures 12 and 13. 


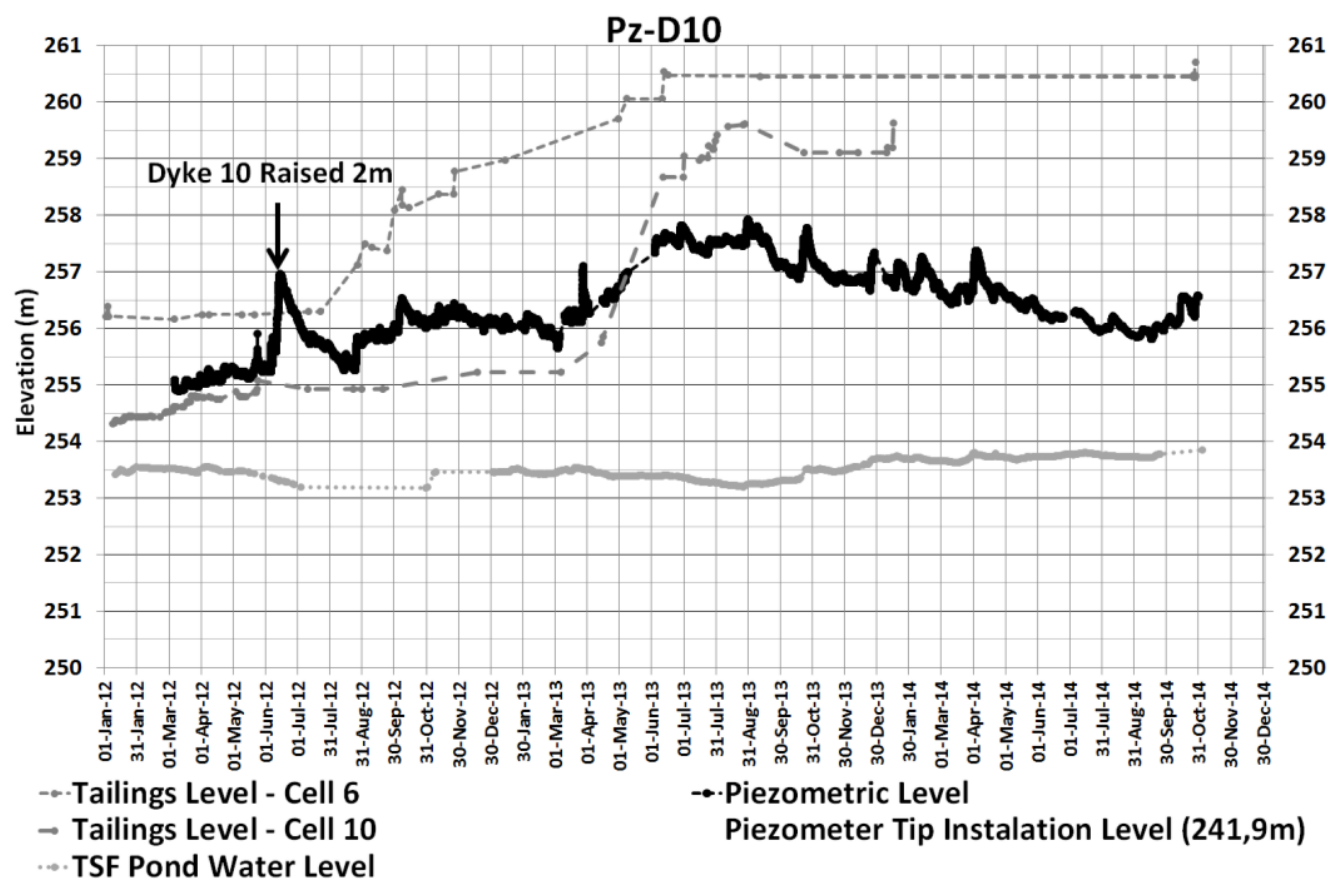

Figure 12 Time evolution of the tailings surfaces and pore pressure at Pz-D10

The notable aspects of Figure 12 are $4 \mathrm{~m} / \mathrm{y}$ rate of rise of the cell 6 tailings (July 2012 to July 2013) and the maximum difference between upstream and downstream tailings elevations of 3 to $4 \mathrm{~m}$ (June 2012 to May 2013).

Neither of these events produced pore pressure levels at the piezometer location which at any time exceeded the tailings surface on the higher side. However, the raising of Dyke 10 in mid-June 2012 (approximately $2 \mathrm{~m}$ raise over a period of one day) spiked the pore pressures temporarily to a level exceeding the surface of the Cell 6 tailings. But these excess pore pressures were quickly dissipated over the next two months, as the graph shows. The graph also shows that pore pressure response to the $4 \mathrm{~m} / \mathrm{y}$ tailings deposition rate was subdued and has dissipated gradually over the last 18 months of repose of this area. 


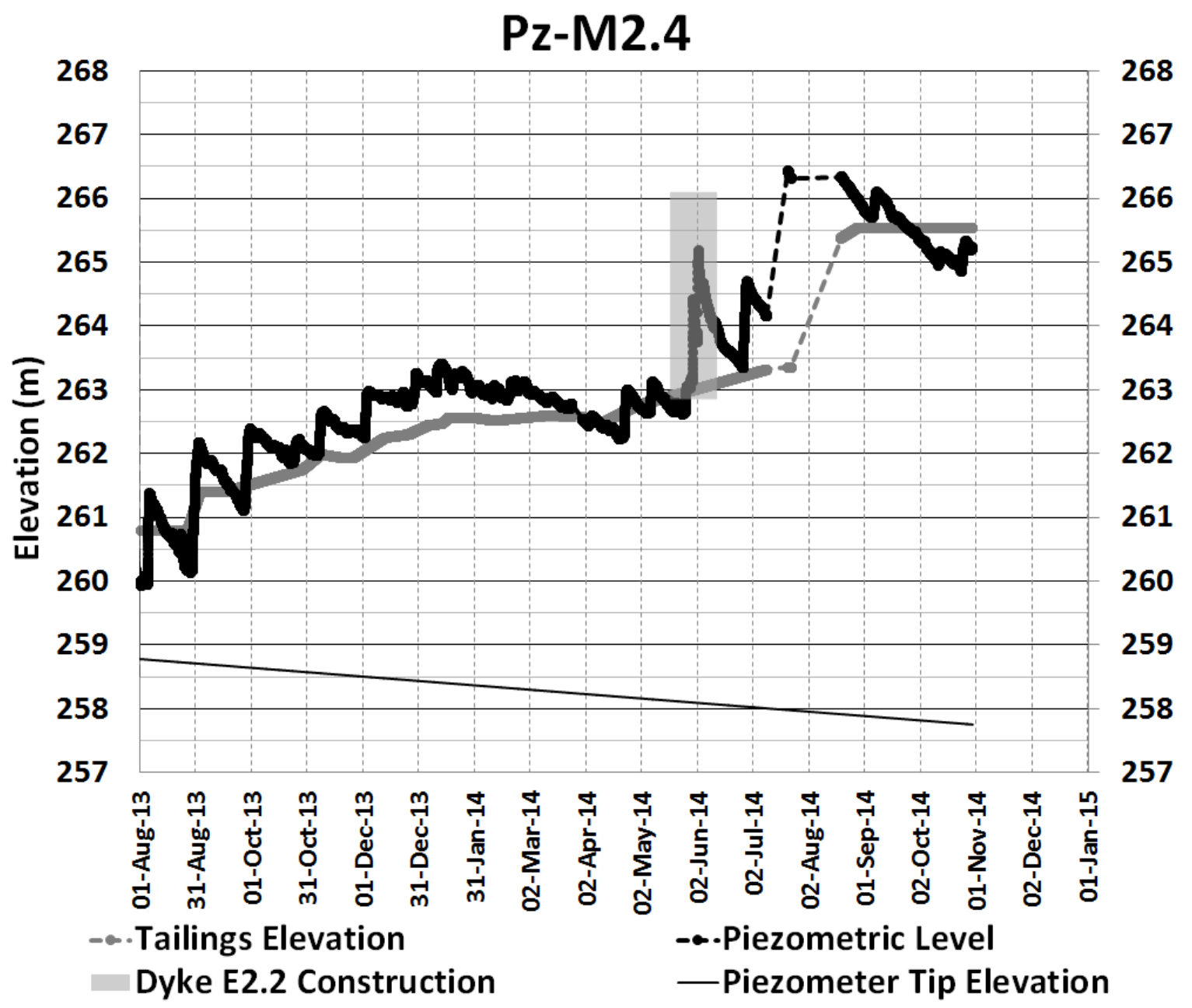

Figure 13 Time evolution of the tailings surfaces and pore pressure at Pz-M2.4

At the cell interior location, the rate of rise of tailings surface between August 2013 and August 2014 was approximately $2.5 \mathrm{~m} / \mathrm{y}$ and there was an exceptional rise of about $2 \mathrm{~m}$ between mid-August and mid-September 2014. The pore pressure response shows that in these interior cell conditions the pore pressure within the thickened tailings, at 2 to $8 \mathrm{~m}$ below surface, can be up to one meter above the tailings surface; a spike of $2 \mathrm{~m}$ occurred during construction of the nearby spigotting berm (Dyke E2.2). During the last two months of deposition repose the pore pressure has been declining at rates similar to the P-D10 case.

\section{$4 \quad$ Conclusions}

Construction of perimeter dams by deposition of slurry tailings which contain a significant fraction of sand sizes is a well-established practice in the mining industry. The segregation of sizes inherent to slurry tailings deposition is a key to establishing a sandy outer wall of tailings with a low phreatic surface which enhances deposit stability. Such upstream raising of tailings deposits is also referred as 'stacking' because they only require a start-up earth or rockfill embankment.

Upstream stacking of thickened tailings has been implemented at the Musselwhite mine (Kam et al. 2011) to expand capacity of an existing conventional sub aerial slurry TSF. At that location the stacking is evolving on the existing beaches of the slurry deposit. At Neves Corvo the thickened tailings stack is being built over subaqueous very loose silt tailings from the outset. This has required extensive investigations and ongoing monitoring of excess pore pressures in the subaqueous tailings and in the developing paste deposit. 
The information provided in this paper shows that a partial stack, some $10.5 \mathrm{~m}$ above the perimeter dams has already been successfully raised by cell construction methods. The monitoring of pore pressure response of the tailings to rates deposition averaging 2 to $4 \mathrm{~m} / \mathrm{y}$, with local cell peaks of up to $2 \mathrm{~m} / \mathrm{month}$, has shown that such deposition rates are tolerable, but continued monitoring is essential due to the inherent variability of the underlying segregated slurry tailings. In instances/locations where pore-pressure rises excessively or dissipation is not occurring the deposition must be halted until adequate dissipation is achieved.

Investigations and stability analyses to date indicate that an overall slope of $4 \%$ will be seismically stable. Subject to confirmation from future periodic CPTu testing of the deposit an overall slope of $6 \%$ may be achievable. These slope geometries will allow raising of the stack to a maximum elevation of about 285 , or some $30 \mathrm{~m}$ above the existing perimeter dam crest.

\section{Acknowledgement}

The authors thank Somincor's management for approval of publication of this paper. Thanks are also due to Nuno Raposo and Eduardo Afonso who conducted most of the laboratory testing.

\section{References}

Been, K \& Jefferies, MG 1985, 'A state parameter for sand', Geotechnique, vol. 35, pp. 99-112.

Junqueira, F, Wilson, G \& Oliveira, M 2009, 'Surface paste disposal of high-sulphide tailings at Neves Corvo Mine in Portugal, part 1: estimation of tailings desaturation and implications on ARG generation', Proceedings of the 8th International Conference on Acid Rock Drainage (ICARD) and Security, the Future: Mining, Metals and the Environment in a Sustainable Society 2009, vol. 1, Curran Associates, Inc., Red Hook.

Kam, S, Girard, J, Hmidi, N, Mao, Y \& Longo, S 2011, 'Thickened tailings disposal at Musselwhite Mine', in RJ Jewell \& AB Fourie, Proceedings of the 14th International Seminar on Paste and Thickened Tailings, Australian Centre For Geomechanis, Perth, pp. 225-236.

Lopes, R, Bahia, R, Jefferies, M \& Oliveira, M 2013, 'Paste deposition over an existing subaqueous slurry deposit of high sulphide content tailings - the Neves Corvo experience', in RJ Jewell, AB Fourie, J Caldwell \& J Pimenta, Proceedings of the 16th International Seminar on Paste and Thickened Tailings, Australian Centre for Geomechanics, Perth, pp. 21-35.

Oliveira, M, Falé, P \& Rodrigues, A 2011, 'Surface paste disposal of high-sulphite tailings part 1 - construction of cells', in A Ofset (ed), Proceedings of the 22nd World Mining Congress and Expo 2011, vol. 2.

Salfate, ER 2011, 'Predicting void ratio for surface paste tailings deposited in thin layers', MSc thesis, University of British Columbia.

Verburg, R, Ross, C \& Oliveira, M 2009, 'Surface paste disposal of high-sulphite tailings at Neves Corvo Mine in Portugal, part 2: field trial cover performance monitoring and impact assessment', Proceedings of the 8th International Conference on Acid Rock Drainage (ICARD) and Security, the Future: Mining, Metals and the Environment in a Sustainable Society 2009, vol. 1, Curran Associates, Inc., Red Hook. 